African Journal of Biotechnology Vol. 11(88), pp. 15438-15445, 1 November, 2012

Available online at http://www.academicjournals.org/AJB

DOI: 10.5897/AJB12.703

ISSN 1684-5315 C2012 Academic Journals

Full Length Research Paper

\title{
Specific aminopeptidases of indigenous Lactobacillus brevis and Lactobacillus plantarum
}

\author{
BELKHEIR Khadidja*, ROUDJ Salima, ZADI KARAM Halima and KARAM Nour Eddine
}

Laboratoire de Biologie des Microorganismes et Biotechnologie (LBMB). Université d’Oran, Algérie.

Accepted 5 September, 2012

\begin{abstract}
Lactic acid bacteria play an important role in milk coagulation and cheese ripening. To select strains showing interesting industrial features, two indigenous lactobacilli (Lactobacillus brevis and Lactobacillus plantarum) were studied for aminopeptidase activity. Cell and cells free extract were tested for leucyl aminopeptidase activity on the chromogenic leucyl-p-nitroanilide substrate. Intracellular and membrane enzymes were solubilized with glycine /lyzozyme treatment then purified by ammonium sulphate precipitation followed by Sephadex G100 and diethylaminoethyl (DEAE) ions exchange chromatography's separation. The molecular weight of denatured proteins was estimated on sodium dodecyl sulfate polyacrylamide gel electrophoresis (SDS PAGE). Effects of several parameters, $\mathrm{pH}$, temperature, some ions and inhibitors on purified enzyme activity were studied. Cellular aminopeptidase activity was higher for CHTD 27 strain than BH14 strain. No aminopeptidase activity was noted in the cell free extract. The results of chromatography sephadex G100 combined to those of electrophoresis allowed suggesting a dimer structure for the native enzyme. The Lb CHTD27 purified enzyme showed maximal activity at $\mathrm{pH} 6.6$ and at $40^{\circ} \mathrm{C}$. This enzyme was partially inhibited by ethylenediamine acetic acid (EDTA) and $\mathrm{Cu}^{2+}$ ions but increased by $\mathrm{Na}^{2+}$ and $\mathrm{Co}^{2+}$ ions. The aminopeptidase extracted from $L b$ BH14 was inhibited by EDTA and phenylmethanesulfonylfluoride or phenylmethylsulfonyl fluoride (PMSF), its maximal activity was observed at pH 7.5 and $40^{\circ} \mathrm{C}$. In addition to other characteristics as proteolysis and autolysis, in this paper we showed that both studied strains were also able to degrade peptide with specific peptidases which are important characters in cheese manufacturing.
\end{abstract}

Key words: Camel milk, Lactobacillus, proteolysis, leucyl aminopeptidase activity.

\section{INTRODUCTION}

Cheese manufacturing includes physical and chemical changes in product followed by flavour characteristics development. These changes are principally attributed to lactic acid bacteria proteolysis, lipolysis and lactose fermentation (Juillart et al., 1996; Mc Sweeney and Sousa, 2000; Børsting and Ardö, 2011). Through their complex enzymatic equipment (proteases, peptidases etc), lactobacilli play an important role in cheese ripening (Khalid and Marth, 1990; Masuda et al., 2005). Among

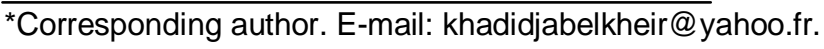

these enzymes, various peptidases hydrolyse peptides into amino acids required for optimal bacterial growth in milk and used as aroma compound precursors (Mierau et al., 1996; Christensen and Steel, 2003; López, 2008). Some lactobacilli enzymes are extracellular but majority are liberated after bacterial cells autolysis (Lortal et al., 1989, 1991; Chapot-Chartier, 1996).

The industrial interest of lactic acid bacteria and their use in health have been the subject of several studies on a large scale, the evolution of knowledge led to the selection and development of new strains. In this way LBMB (Laboratoire de Biologie des Microorganismes et Biotechnologie de l'Université d'Oran ALGERIE) set the 
goal of preparing a collection of indigenous interesting lactic acid bacteria strains (Karam, 1995).

In order to select lactobacilli which showed technological traits, in this study we studied leucyl aminopeptidase activity of Lactobacillus brevis CHTD27 and Lactobacillus plantarum $\mathrm{BH} 14$ isolated from camel milk. This type of enzyme contributes to bitterness reduction (Thivierge, 1999; Tchorbanov et al., 2011), so strains which present this activity are in demand.

\section{MATERIALS AND METHODS}

\section{Bacterial strains and culture conditions}

L. brevis $\mathrm{CHTD} 27$ and $L$. plantarum $\mathrm{BH} 14$ used in this study were originally isolated from raw camel milk collected in Tindouf and Timmimoun areas respectively for CHTD27 and BH14. They were previously selected as proteolytic and autolytic strains (Roudj et al., 2009). Bacterial growth was prepared in MRS broth (Man et al., 1963) at $30^{\circ} \mathrm{C}$ for $24 \mathrm{~h}$.

\section{Enzymes assay}

Aminopeptidase (AP) activity was tested by using chromogen leucyl paranitroanilide substrate prepared at $20 \mathrm{mM}$ in absolute methanol according to the method of El Soda and Desmazeaud (1982). Reaction mixture contained $200 \mu \mathrm{l}$ potassium phosphate buffer $(0.1 \mathrm{M} \mathrm{pH7.0)}, 25 \mu \mathrm{l}$ of substrate (freshly prepared) and $50 \mu \mathrm{l}$ of enzyme. The mixture was incubated at $37^{\circ} \mathrm{C}$ for $24 \mathrm{~h}$. The reaction was stopped by adding $300 \mu \mathrm{l}$ of acetic acid solution (10\%). After centrifugation (12000 rpm/10 min), supernatant absorbance was read against control sample prepared and incubated similarly without enzyme. Hydrolysis of substrate and nitroanilide liberation was determined by measuring absorbance at $410 \mathrm{~nm}$. The supernatant of liquid culture (MRS/2\% milk) and cells were tested for AP activity as described above.

\section{Effects of pH and temperature on cell aminopeptidase activity}

Effects of $\mathrm{pH}$ and temperature on cell AP activity were determined to carry all steps of partial purification of aminopeptidase at both optimum $\mathrm{pH}$ and optimum temperature. Cell cultures were incubated at $6,20,30,40,50$ and $60^{\circ} \mathrm{C}$. For $\mathrm{pH}$ effect, medium was prepared by potassium phosphate buffer $0.1 \mathrm{M}$ at $\mathrm{pH} 5,6,6.1,6.9$, 7.3 or 8.3

\section{Extraction, purification and characterization of enzyme}

\section{Preparation of cell free extract}

Enzymes were extracted from cells by both actions of glycine and lysozyme. Cells culture was prepared on MRS medium supplemented with $4 \%$ glycine. After $18 \mathrm{~h}$ of incubation at $37^{\circ} \mathrm{C}$ optical density $\left(\mathrm{OD}_{640 \mathrm{~nm}}=1\right)$, cells were collected by centrifugation $(12000$ $\mathrm{rpm} / 10 \mathrm{~min} / 4^{\circ} \mathrm{C}$ ). The pellet was washed twice with potassium phosphate buffer $(0.1 \mathrm{M} \mathrm{pH} 7.0)$ and suspended in the same buffer supplemented with $10 \mathrm{mM}$ of lysozyme. After $2 \mathrm{~h}$ of lysozyme treatment at $37^{\circ} \mathrm{C}$, the mixture was centrifuged $(12000 \mathrm{rpm} / 10$ $\min / 4^{\circ} \mathrm{C}$ ). The resulting supernatant was designed as the cell free extract.

\section{Partial purification of aminopeptidases}

For both strains the cell free crude was fractioned by salting out using two concentrations $50 \%$ then $80 \%$ of solid ammonium sulfate (Goldsteine et al., 2002).

The ammonium sulfate protein fraction was dissolved in $0.1 \mathrm{M}$ potassium phosphate buffer $\mathrm{pH} 7.0$ and dialysed in first against distilled water then against sucrose. The 3 times concentrated fraction was applied to Sephadex G100 (Pharmacia) column $(20 \times$ $1.2 \mathrm{~cm}$ ) equilibrated with Tris- $\mathrm{HCl} 0.05 \mathrm{M} \mathrm{pH} 7.0$ buffer. Proteins were eluted by the same buffer, and fractions of $1.5 \mathrm{ml}$ were collected. The active fraction obtained after the first chromategraphy was loaded on to a DEAE cellulose (D52 Whatman) column prepared as described by Deneuville (1991). Enzymes were eluted by discontinuous gradient of $\mathrm{NaCl}(1 \%$ then $3 \%)$ in potassium phosphate buffer $(0.1 \mathrm{M} \mathrm{pH} 7.0)$. Fractions of $2 \mathrm{ml}$ were recuperated.

Proteins concentrations were determined by the method of Bradford (1976) using BSA as standard. The molecular weights of the denatured enzymes were estimated by SDS gel electrophoresis (SDS PAGE) using (5\%) stacking gel and (13\%) resolving gel and weight markers (Catalase $250 \mathrm{kDa}$, BSA $67 \mathrm{kDa}$, Olvabumin 43 $\mathrm{kDa}$, Pepsin A $35 \mathrm{kDa}$, Chymotrypsin $25 \mathrm{kDa}$ ) prepared according to the method of Laemmli (1970).

\section{Effect of $\mathrm{pH}$ and temperature on enzyme activity}

The effect of temperature on aminopeptidase activity was determined after $15 \mathrm{~min}$ incubation of enzyme at 30,40 or $50^{\circ} \mathrm{C}$ prior to add the substrate then the mixtures was incubated for $24 \mathrm{~h}$. The effect of $\mathrm{pH}$ was studied by using potassium phosphate buffer 0.1 $\mathrm{M}$ at $\mathrm{pH} 5.1,5.6,6.6,7.5$ or 8.0. The enzyme was previously incubited $15 \mathrm{~min}$ in each buffer before adding substrate. Incubation was extended for $24 \mathrm{~h}$ at $40^{\circ} \mathrm{C}$.

\section{Effect of inhibitors agents and metal ions on enzyme activity}

Effects of chemicals agents phenylmethylsulfonylfluoride (PMSF), $\beta$-mercaptoethanol, EDTA ( $5 \mathrm{mM}$ then $10 \mathrm{mM}$ ), and the following di-ionic agents $\mathrm{CoCl}_{2}, \mathrm{CaCl}_{2}, \mathrm{KCl}, \mathrm{ZnCl}_{2}, \mathrm{NaCl}, \mathrm{MnCl}_{2}, \mathrm{MgCl}_{2}, \mathrm{CuCl}_{2}$ ( $5 \mathrm{mM}$ then $10 \mathrm{mM}$ ) were determined. Chemicals inhibitors and ions were added to the reaction (potassium phosphate buffer $0.1 \mathrm{M} \mathrm{pH}$ $6.9+$ enzymes). Mixture was incubated for $15 \mathrm{~min}$ at $40^{\circ} \mathrm{C}$ before adding substrate then the incubation was extended for $24 \mathrm{~h}$ in the same temperature.

In every case, enzyme activity was expressed as the percentage of activity obtained with or without the studied compound. Every experience was repeated many times (more than 3 tubes were prepared during the OD measure) for the result confirmation.

\section{RESULTS}

\section{Aminopeptidase activity}

The two studied strains produced aminopeptidases, it was revealed by hydrolysis of the chromogen substrate which becomes yellow (measured at $410 \mathrm{~nm}$ ) after liberation of nitroanilide.

This activity was important for cells of $L$. brevis CHTD27 $\left(\mathrm{OD}_{410 \mathrm{~nm}}=2.85\right)$ then the cells of $L$. plantarum $\mathrm{BH} 14\left(\mathrm{OD}_{410 \mathrm{~nm}}=1.96\right)$. A negligible AP activity was noted in the extracellular supernatant of liquid culture, $\mathrm{OD}_{410 \mathrm{~nm}}=$ 
Table 1. Results of purification steps.

\begin{tabular}{cccccc}
\hline Fraction & Protein $(\mathbf{m g})$ & Cat act (nanokat) & Sp act (nanokat/mg) & P & R (\%) \\
\hline CHTD27 & & & & & \\
CFE & 1340 & 193.52 & 0.144 & 1.00 & 100 \\
SA 80 & 294.83 & 159.21 & 0.54 & 3.75 & 82.27 \\
G100 & 65 & 70.69 & 1.09 & 7.55 & 36.52 \\
DEAE & 38 & 45.98 & 1.21 & 8.40 & 23.76 \\
& & & & & \\
BH14 & & & & & \\
CFE & 980.00 & 134.50 & 0.14 & 1.00 & 100 \\
SA & 263.52 & 131.76 & 0.50 & 3.57 & 97.96 \\
G100 & 80.0 & 56.27 & 0.70 & 5.02 & 29.10 \\
DEAE & 12.38 & 8.92 & 0.72 & 5.14 & 6.63 \\
\hline
\end{tabular}

CFE: crude free extract; $\mathbf{S A}_{80}$ : 80\% ammonium sulphate saturation; G100: Sephadex G100 chromatography; DEAE: DEAE cellulose chromatography; Cat act: catalytic activity; $\mathbf{S p}$ act: specific activity; $\mathbf{P}$ : purity; R: yield.

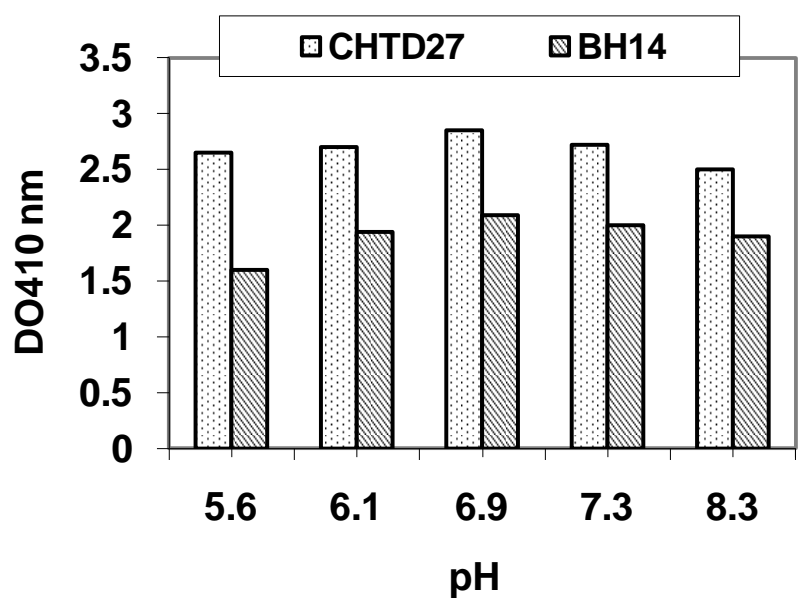

Figure 1. Effect of $\mathrm{pH}$ on cells AP activities.

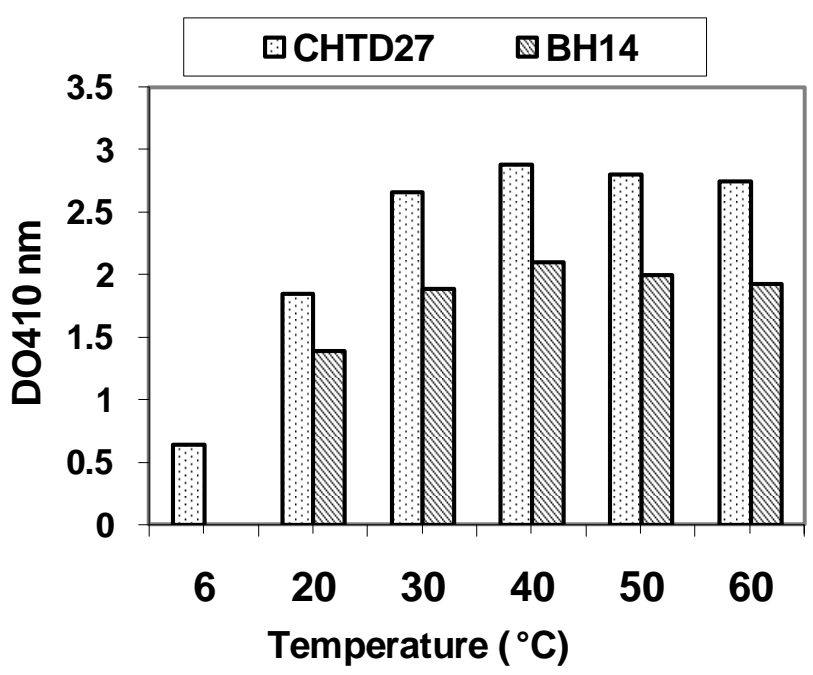

Figure 2. Effect of temperature on cells AP activities.
0.0815 for $L$. brevis CHTD27 and $\mathrm{OD}_{410 \mathrm{~nm}}=0.0915$ for $L$. plantarum $\mathrm{BH} 14$.

\section{Optimal conditions of cells aminopeptidase activities}

Temperature and $\mathrm{pH}$ conditions were examined in order to have maximal cells AP activities for the remaining work. According to the results (Figures 1 and 2), maximal activities were obtained for both strains at temperature of $40^{\circ} \mathrm{C}$ and at $\mathrm{pH}$ 6.9. These two parameters were retained for the following steps.

\section{Subcellular localisation of aminopeptidase}

\section{Enzyme extraction}

Various procedures were used for cells aminopeptidase extraction (toluene, potassium phosphate buffer $0.1 \mathrm{M} \mathrm{pH}$ $7.2, \mathrm{NaCl} 0.9 \%$ ). These methods proved to be inefficient and they trained interference problems with chromogen substrate during measuring. The method assembling culture in the presence of glycine and lysozyme treatment allowed the extraction of these enzymes, effectively, catalytic activities reached 0.144 nanokatals $/ \mathrm{mg}$ for $\mathrm{L}$. brevis CHTD27 and about 0.1 nanokatals/mg for $\mathrm{L}$. plantarum $\mathrm{BH} 14$ as measured in brute extracts (Table 1).

\section{Enzymes purification from extract}

The specific peptidase activity observed with Leu-pNA as substrate at each purification step is presented in Table 1. The enzyme was purified about 9-fold from the CHTD27 cell-free extract and 5 fold from the BH14 cellfree extract. Chromatograms are shown in Figures 3 and 4. 

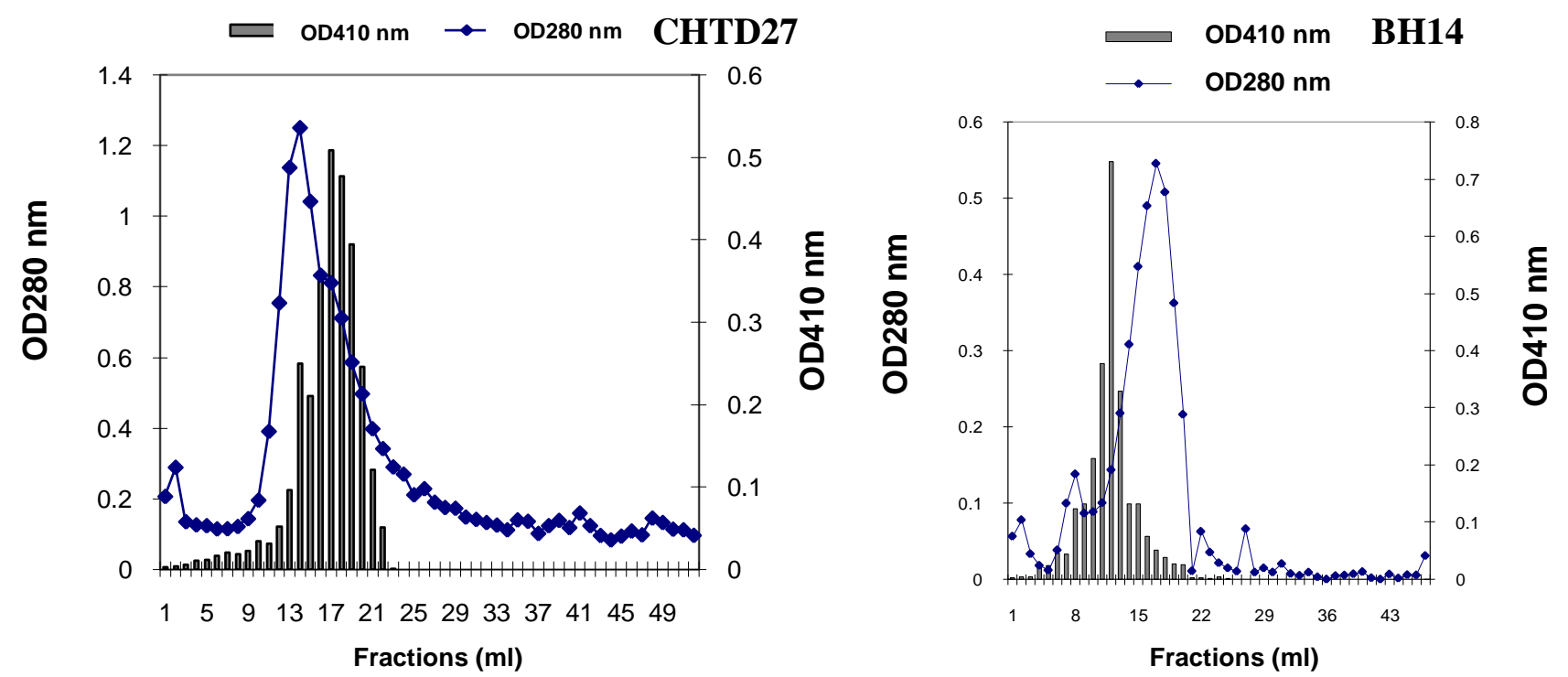

Figure 3. Séphadex $\mathrm{G} 100$ chromatograms of $\mathrm{SA}_{80}$ fraction. Absorbance of protein contents was measured at $280 \mathrm{~nm}$ and of $\mathrm{AP}$ activity at $410 \mathrm{~nm}$.

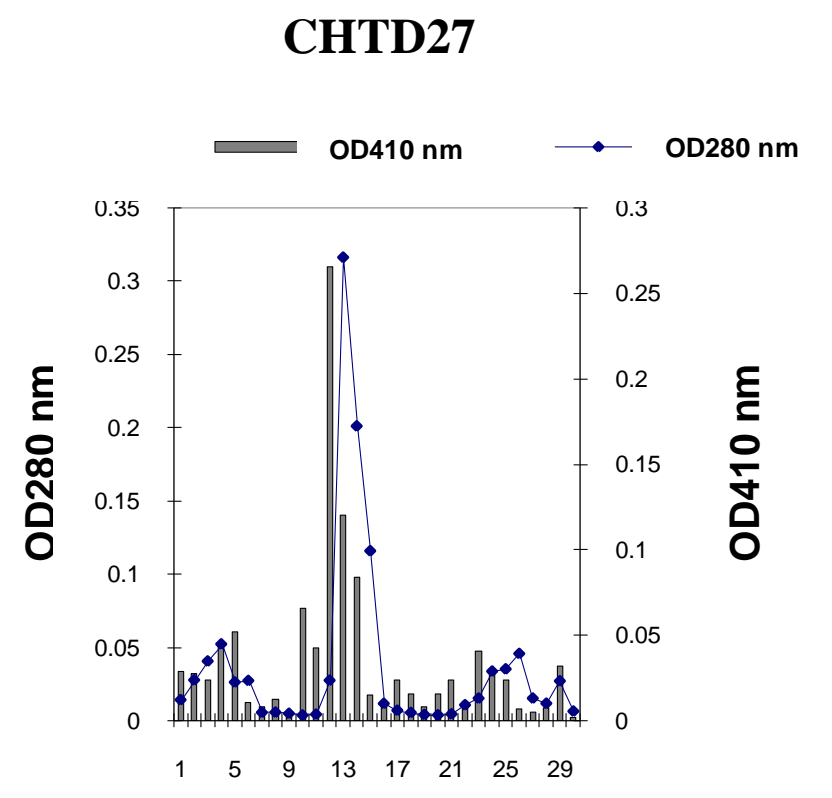

Fractions (ml)

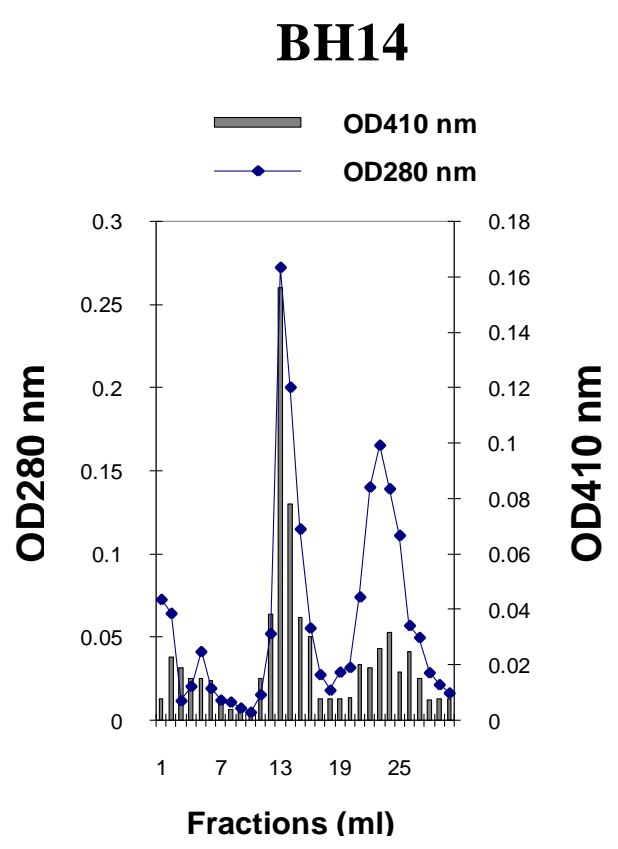

BH14

Figure 4. DEAE Cellulose Chromatograms of G100 fractions. Absorbance of protein contents was measured at $280 \mathrm{~nm}$ and of AP activity at $410 \mathrm{~nm}$.

\section{Electrophoretical analysis of the purified enzymes}

The molecular weight of the purified enzyme as estimated by sodium dodecyl sulfate polyacrylamide gel electrophoresis (SDS PAGE) was about $43 \mathrm{kDa}$ (Figure 5). The molecular mass of the native enzyme was previously estimated to be close to $100 \mathrm{kDa}$ by Sephadex G100 column filtration and hence both results allowed suggesting that the native enzyme is a dimeric molecule.

\section{Biochemical characteristics of the purified enzymes}

Effects of several parameters, $\mathrm{pH}$, temperature, ions and inhibitors on enzyme activity were evaluated and results 

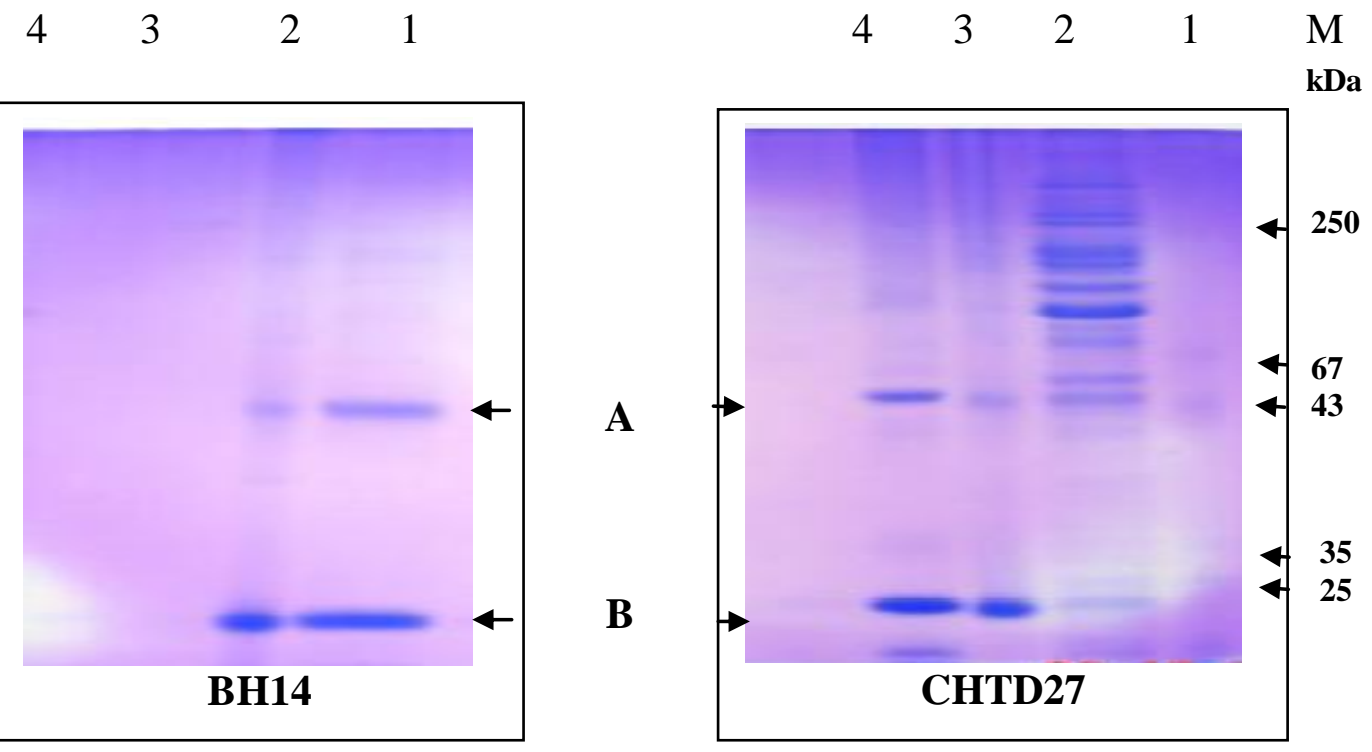

Figure 5. Electrophoresis of the different enzymatic fractions. Lanes: 1: Crude extract; 2: Ammonium sulphate precipitation fraction; 3: Sephadex G100 fraction; 4: DEAE fraction; M: MW markers. Arrows indicate bands of: A: Aminopeptidase; B: Lyzozyme.

Table 2. Effects of several parameters on AP activity.

\begin{tabular}{|c|c|c|c|c|}
\hline Stains parameter & \multicolumn{2}{|c|}{ CHTD27 (\%) } & \multicolumn{2}{|c|}{ BH14 (\%) } \\
\hline \multicolumn{5}{|l|}{ Temperature $\left({ }^{\circ} \mathrm{C}\right)$} \\
\hline 30 & \multicolumn{2}{|c|}{87.5} & \multicolumn{2}{|c|}{85} \\
\hline 40 & \multicolumn{2}{|c|}{100} & \multicolumn{2}{|c|}{100} \\
\hline 50 & \multicolumn{2}{|c|}{46} & \multicolumn{2}{|c|}{90} \\
\hline \multicolumn{5}{|l|}{ pH } \\
\hline 5.0 & \multicolumn{2}{|c|}{27.6} & \multicolumn{2}{|c|}{58.7} \\
\hline 5.6 & \multicolumn{2}{|c|}{34.6} & \multicolumn{2}{|c|}{79.5} \\
\hline 6.6 & \multicolumn{2}{|c|}{100} & \multicolumn{2}{|c|}{85.4} \\
\hline 7.5 & \multicolumn{2}{|c|}{67.8} & \multicolumn{2}{|c|}{100} \\
\hline 8.0 & \multicolumn{2}{|c|}{40.5} & \multicolumn{2}{|c|}{73.3} \\
\hline Inhibitor & $5 \mathrm{mM}$ & $10 \mathrm{mM}$ & $5 \mathrm{mM}$ & $10 \mathrm{mM}$ \\
\hline PMSF & 94.42 & 64.6 & 92.44 & 25.7 \\
\hline$\beta$-mercaptoethanol & 98.07 & 92.3 & 166.6 & 98.94 \\
\hline EDTA & 76.9 & 76.9 & 47 & 35 \\
\hline \multicolumn{5}{|l|}{ lons } \\
\hline $\mathrm{CaCl}_{2}$ & 77.35 & 89.14 & 76.68 & 96 \\
\hline $\mathrm{KCl}$ & 76.71 & 87.42 & 100 & 100 \\
\hline $\mathrm{ZnCl}_{2}$ & 61.84 & 64.24 & 98.94 & 98.9 \\
\hline $\mathrm{NaCl}$ & 68.8 & 141 & 92.9 & 101.1 \\
\hline $\mathrm{MnCl}_{2}$ & 77.51 & 106.2 & 51.4 & 100 \\
\hline $\mathrm{MgCl}_{2}$ & 66.08 & 74.5 & 101.1 & 100 \\
\hline $\mathrm{CuCl}_{2}$ & 54.5 & 28.2 & 30.5 & 27.6 \\
\hline $\mathrm{CoCl}_{2}$ & 77.1 & 130 & 102.3 & 101.1 \\
\hline
\end{tabular}

The percentage represents the residual activity. 
are summarized in Table 2. The enzyme extracted from $\mathrm{BH} 14$ strain was activated by $\beta$ mercaptoethanol at 10 $\mathrm{mM}(166.6 \%)$ and strongly inhibited by EDTA (35\%) and PMSF at $10 \mathrm{mM}(25.7 \%)$ while the enzyme extracted from CHTD27 strain was partially inhibited by EDTA and PMSF; however no effect of $\beta$ mercaptoéthanol was observed on this enzyme. For both strains the AP activity was strongly inhibited by $\mathrm{Cu}^{+2}(54.5 \%, 28.2 \%$ for CHTD27 and $27.6 \%, 30.5 \%$ for $\mathrm{BH} 14$ ) respectively at 5 and $10 \mathrm{mM}$. The maximum of the enzymatic activity was noted at $\mathrm{pH} 6.6$ and $40^{\circ} \mathrm{C}$ for CHTD27 and $\mathrm{pH} 7.5$ and $40^{\circ} \mathrm{C}$ for $\mathrm{BH} 14$.

\section{DISCUSSION}

The two studied strains express variation in cell aminopeptidases activity which was also reported by Thivierge (1999) for mesophilics Lactococcus strains and Liu et al. (2010) for lactobacilli strain. The absence of aminopeptidase activity in extracellular fraction allowed us to conclude that the studied enzyme is not or little exuded in the extracellular medium by our strains. Membrane and cytoplasm localisations were usually indicated for lactobacilli pepN (Eggimann and Bachmann, 1980; Atlan et al., 1989, 1990; Cholette and Mc Kellar, 1990; Tsakalidou et al., 1993; Choi et al., 1995; Macedo et al., 2003; Pan and Tanokura, 2004). These results are evident because such enzyme plays an important role in cellular nutrition by supplying requisites amino acids for cells growth. The extracellular liberation of such enzymes leads cells to not use milk caseins, so it is not the case for lactic acid bacteria and notably for lactobacilli which use the caseins in milk as an additional source of nitrogen (Monnet et al., 1993; Pritchard and Coolbear, 1993).

The two strains synthesized aminopeptidases during logarithmic stage of growth between 6 and $18 \mathrm{~h}$ of culture. This activity was stable during stationary phase of growth. Reduction in production of AP was noted with cellular density diminution (after $20 \mathrm{~h}$ of culture). This cells autolysis was not accompanied by AP activity augmentation (Roudj et al., 2009). This may indicate a membrane localisation for enzymes of both strains.

To extract enzymes we prepared the culture in the presence of glycine then cells were kept under lysozyme action. Several techniques for extracting AP from cells have been cited in the literature such as osmotic shock (Sanz and Toldra, 2002; Tsakalidou et al., 1993; Monnet et al., 1995; Tobiassen et al., 1997; Magboul and Sweeney, 1999a, Sanz and Toldra, 2002;), lysozyme and ultrasonic treatments or cell French Pressure (Eggimann and Bachmann, 1980; Miyakawa et al., 1992) or glass beads Beater (Bolumar et al., 2003).

Enzyme extraction by glycine/lysozyme treatment supports membrane AP localisation hypothesis for both studied strains. When cultured with high concentration of glycine, growing cells incorporate this molecule into their wall, which replace alanine at different positions in peptidoglycan, so wall is fragilized and protease are easily liberated (Hammes et al., 1973). The lysozyme treatment destroys membrane o-sides links.

The purified enzymes showed a dimeric structure concluded from electrophoresis and gel filtration chromatography results. This result is similar to the result of other authors obtained for peptidase of $L$. curvatus DPC2024 and L. plantarum ESB5004 (Magboul and Sweeney, 1999a; Macedo et al., 2003). However, the dimeric structure differs from work which spoke about monomeric or trimeric Lactobacillus peptidases (Eggimann and Bachmann, 1980; Miyakawa et al., 1992; Tsakalidou et al., 1993; Gobbetti et al., 1996; Pan and Tanokura, 2004). Results obtained for L. plantarum $\mathrm{BH} 14$ and L. brevis CHTD27 and those of other authors for lactobacilli strains demonstrate an important diversity of AP in Lactobacillus group (El soda et al., 1983). Effectively mesophilic homofermentative lactobacilli, mainly L. brevis, L. casei, L. paracasei, L. plantarum and $L$. curvatus are the common strains of nonstarter culture incoporated into starter microflora to control and accelerate cheese ripening by numerous peptidases (Tobiassen et al., 1997). These peptidases are encoded in all lactic acid bacteria genomes usually with one gene per genome. For instance, aminopeptidases PepC, PepN, and PepM, and proline peptidases PepX and PepQ are present in all genomes, some lactic acid bacteria genomes have two peptidase homologs, possibly with the same function (Liu et al., 2010). Other essential peptidases such as endopeptidase PepO and dipeptidase PepV are encoded by multiple paralogous genes (Liu et al., 2010).

Aminopeptidase of $L$. brevis CHTD27 has characteristics usually observed in aminopeptidases of other Lactobacillus strains. It is like to be a metallo protein activated by $\mathrm{Co}^{2+}$ and inhibited by $\mathrm{Cu}^{2+}$. The optimum $\mathrm{pH}$ and temperature values for maximal enzyme activity were respectively 6.9 and $40^{\circ} \mathrm{C}$ (Eggimann and Bachmann, 1980; Gobbetti et al., 1996; Tsakalidou et al., 1993; Sanz and Toldra, 2002; Nandan et al., 2010).

Aminopeptidase extracted from L. plantarum $\mathrm{BH} 14$ is different; it is a metallo enzyme with serine in its catalytic setting. The enzyme activity was inhibited by $\mathrm{Cu}^{2+}$ ions and the maximum of this activity was observed at $\mathrm{pH} 7.5$ and $40^{\circ} \mathrm{C}$. Some Lactobacillus aminopeptidases have also thiol or cysteine groups in their catalytic sites (Miyakawa et al., 1992; Magboul and Mc Sweeney, 1999b). L. plantarum $\mathrm{BH} 14$ aminopeptidase activity was increased by $\beta$ mercaptoethanol. This rise was explained by the $\mathrm{pH}$ conditions of the reactive mixture according to Cholette and Mc Kellar (1990). According to literature, gene analysis suggests that some peptidases genes in Lactobacillus strains share the same neighbor genes, except for L. plantarum and both for L. brevis (El soda et al., 
1983, Liu et al., 2010). For example the L. plantarum pepM gene (LPL_28377183) is flanked by a methionine metabolism related operon (cysK_cblB/cglB_cysE). Therefore, the pepM gene in L. plantarum may have a broader function, probably utilizing proteins and peptides as methionine pool, in addition to the classic PepM function for N-terminal maturation of proteins (Liu et al., 2010).

\section{Conclusion}

Our investigation contributed to acquire more knowledge about properties of enzymes by study proteolysis of two indigenous Lactobacilli isolated from raw Algerian camel milk to select new strains with interesting technological traits requisite in cheese manufacturing. The two strains have extracellular proteolytic and high autolytic activities (Roudj et al., 2009), desirables characteristics in milk coagulation and cheese ripening (El Soda et al., 2000; Madkor et al., 2000; Liu et al., 2010; El-Tanboly et al., 2010). In this paper we proved that these strains are able to hydrolyse leucyl paranitroanilide by particular aminopeptidase which is also an important character to avoid bitterness during milk coagulation. For their proteolytic and autolytic activities the two strains can be used as starter culture necessary in the early stages of cheese production or as nonstarter culture which contribute to flavor development in some varieties of cheeses. These strains can be used in culture alone or with other types of lactic acid bacteria Leuconostoc, Lactococcus, or with others microorganisms as yeast or fungal in mixed culture (closed mixed).

The aminopeptidase activity was slightly important for cells of $L$. brevis CHTD27 then L. plantarum BH14. The enzymes implicated in this activity are metalloenzymes with maximal activity at $40^{\circ} \mathrm{C}$ for both strains. Aminopeptidases of Lactobacillus brevis CHTD27 presented properties usually noted in $\mathrm{N}$ aminopeptidases isolated from Lactobacilli, the one obtained from Lactobacillus plantarum BH14 showed particular characteristics observed in some Lactobacillus. Our results point to that these enzymes are composed of two subunits with molecular weight of $43 \mathrm{kDa}$ which is a result already watched for some Lactobacillus aminopeptidases. In further work we need to test these peptidases on the caseinolytic products especially when some Lactobacillus strains have positive effect on cheese flavour ( $L$ plantarum, $L$ casei) and others are responsible for bitterness development like L. brevis (Khalid and Marth, 1990; Tobiassen et al., 1997; Tchorbanov et al., 2011).

\section{REFERENCES}

Atlan D, Laloi P, Portalier R (1989). Isolation and characterization of aminopeptidase deficient $L b$ bulgaricus mutants. Appl. Environ. Microbiol. 55:1717-1723.
Atlan D, Laloi P, Portalier R (1990). X-prolyl-dipeptidyl aminopeptidase of $L b$ delbrueckii subsp bulgaricus characterization of enzyme and isolation of deficient mutants. Appl. Environ. Microbiol. 56:2174-2179.

Bolumar T, Sanz Y, Aristoy MC, Toldra F (2003). Purification and characterization of a prolyl aminopeptidase from Debaryomyces hansenii. Appl. Envir. Microbiol.69:227-232.

Børsting MW, Ardö Y (2011). Influence of proteolysis and amino acid release on quality of reduced-fat Cheddar cheese. Faculty of life sciences. University of Copenhagen.

Bradford MM (1976). A rapid and sensitive methode for quantification of microgram quantities of protein, utilizing the principale of protein dyebinding. Annal. Biotechnol. 72:248-254.

Chapot-Chartier MP (1996). Les autolysines des bactéries lactiques. Laits 76:91-109.

Choi H, Laleye L, Amanta GF, Simard RE (1995). Production of aminopeptidase from skim milk whey permeate medium by Lactobacillus casei ssp.casei. J. Dairy Sci. 79:956-963.

Cholette H, McKellar RC (1990). Influence of $\mathrm{pH}$ on the properties of Lactobacillus helveticus aminopeptidase. J. Dairy Sci. 73:2278-2286.

Christensen JE, Steel JL (2003). Impaired growth rates in milk of $L b$ helveticus peptidase mutants can be overcome by use of amino acid supplements. J. Bacteriol.185:3297-3306.

Deneuville F (1991). Génie fermentaire travaux pratiques. Édition Doin.

Eggimann B, Bachmann M (1980). Purification and partial characterization of an aminopeptidase from Lactobacillus lactis. Appl. Environ. Microbiol. 40:876-882.

El Soda M, Desmazeaud MJ (1982). Les peptide-hydrolases des Lactobacilles du groupe Thermobacterium.I. Mise en evidence de ces activités chez Lactobacillus helveticus, Lactobacillus acidophilus, Lactobacillus lactis et Lactobacillus bulgaricus. Canadian. J. Microbiol. 28:1181-1188.

El Soda M, Madkor A, Tong PS (2000). Adjunct cultures: Recent developments and potential significance to the cheese industry. J. Dairy Sci. 83:608-619.

El Soda M, Said H, Desmazeaud M J, Mashaly R, Ismail A (1983). The intracellular peptide-hydrolases of Lactobacillus plantarum. Comparison with Lactobacillus casei. Lait, 63, 1-14.

El-Tanboly ES, El-Hofi M, Abd-Rabou NS, El-Desoki W (2010). Contribution of mesophilic starter and adjunct lactobacilli to proteolysis and sensory properties of semi hard cheese. Journal of American Science. 6(9).

Gobbetti M, Smacchi E, Corsetti A (1996). The proteolytic system of Lactobacillus sanfrancisco CB1: purification and characterization of proteinase, a dipeptidase and aminopeptidase. Appl. Environ. Microbiol. 62:3220-3226.

Goldstein JM, Nelson D, Kordula T, Mayo JA, Travis J (2002). Extracellular arginine aminopeptidase from Streptococcus gordonii FSS2. Infection and immunity. 70:836-843.

Hammes W, Schleifer KH, Kandler O (1973). Mode of action of glycinee on the biosynthesis of peptidaglycan. J. Bacteriol. 116:1029-1053.

Juillart V, Focaud C, Desmazeaud M, Richard J (1996). Utilisation des sources d'azote du lait par Lactococcus lactis. Lait. 76:13-24.

Karam NE (1995). Constitution d'un souchier de bactéries lactiques à intérêt biotechnologique : Etude biochimique et moléculaire. Thèse de doctorat d'Etat. Université d'Oran.

Khalid NM, Marth EH (1990). Lactobacilli -their enzymes and role in ripening and spollage of cheese: a review. J. Dairy Sci. 73:26692684.

Laemmli UK (1970). Cleavage of structural protins during the assembly of the head of bacteriophageT4. Nature, 227(5259) :680-685.

Liu M, Bayjanov JR, Renckens B, Nauta A, Siezen RJ (2010). The proteolytic system of lactic acid bacteria revisited: a genomic comparison. BMC Genomics 11:36.

López Kleine $L$ (2008). Détermination du rôle de certaines peptidases bactériennes par inférence à partir de données hétérogènes et incomplètes. Thèse pour l'obtention du grade de docteur. France.

Lortal S, Boyaval P, Van Heijenoort J (1989). Influence de plusieurs facteurs sur l'autolyse de Lactobacillus helveticus CNRZ 414. Lait 69:223-231.

Lortal S, Rousseau M, Boyaval P, Van Heijenoort J (1991). Cell wall 
and autolytic system Lactobaci/lus helveticus ATCC 12046. J. Gen. Microbiol. 137:549-559.

Miyakawa H, Kobayashi S, Shimamura S , Tomita M (1992). Purification and characterization of an aminopeptidase from Lactobacillus helveticus LHE-511. J. Dairy Sci., 75 :27-35

Macedo A, Tavares T, Malcata FX (2003). Purification and characterization of an intracellular aminopeptidase from a wild strain of Lactobacillus plantarum isolated from traditional serra da estrela cheese. J. Enzym. Microbiol. Technol. 32:41-48.

Madkor SA, Tong PS, El Soda M (2000). Ripening of Cheddar Cheese with Added Attenuated Adjunct Cultures of Lactobacilli. J. Dairy Sci. 83:1684-1691.

Magboul AAA, Mc Sweeney PLH (1999a). PepN-like aminopeptidase from Lactobacillus curvatus DPC2024: Purification and characterization. Lait 79:515-526.

Magboul AAA, Mc Sweeney PLH (1999b). Purification and characterization of an aminopeptidase from Lactobacillus curvatus DPC2024. Int. Dairy J. 9:107-116.

Man JC, Rogosa M, Sharpe ME (1960). A médium for cultivation of Lactobacilli. J. Appl. Bacteriol., $23: 130-135$

Masuda T, Hidaka A, Kondo N, Ura T, Itoh T (2005). Intracellular Enzyme Activities and Autolytic Properties of Lactobacillus Acidophilus and Lactobacillus Gasseri. Food Sci. Technol. Res. 11:328-331.

Mc Sweeney PLH, Sousa MJ (2000). Biochemical pathways for the production of flavour compounds in cheeses during ripening: a review. Lait 80:293-324.

Mierau I, Kunji ERS, Leenhouts KJ, Hellendroon MA, Haandrikman AJ, Poolman B, Konings WN, Venema G, Kok J (1996). Multiple peptidase mutants of Lactococcus lactis are severely impaired in their ability to grow in milk. J. Bacteriol. 178:2794-2803.

Miyakawa H, Kobayashi S, Shimamura S, Tomita M (1992). Purification and characterization of an aminopeptidase from Lactobacillus helveticus LHE-511. J. Dairy Sci. 75:27-35.

Monnet MC, Seronie MP, Talon R, Hebraud M (1995). Purification and characterization of a dipeptidase from Lactobacillus sake. Appl. Environ. J. Microbiol. 61:837-839.

Monnet V, Chapot-Chartier MP, Gripon JC (1993). Les peptidases des Lactocoques. Lait 73:97-108.
Nandan A, Gaurav A, Pandey A, Madhavan Nampoothiri K (2010). Arginine Specific Aminopeptidase from Lactobacillus brevis. Brazilian Arch. Biol. Technol. 53(6):1443-1450.

Pan D, Tanokura M (2004). Purification and characterization of an aminopeptidase from Lactobacillus helveticus JCM1004. J. Food Chem. 88:511-516.

Pritchard G, Coolbear T(1993). The physiology and biochemistry of the proteolytic system in lactic acid bacteria. FEMS Microbiol. Rev.,12:179-206

Roudj S, Belkheir K, Zadi Kram H, Karam N (2009). Protéolyse et autolyse chez deux lactobacilles isolés de lait camelin du Sud Ouest Algérien. Eur. J. Sci. Res. 34:218-227.

Sanz Y, Toldra F (2002). Purification and characterization of an arginine aminopeptidase from Lactobacillus sakei. Appl. Environ. J. Microbiol. 68:1980-1987.

Tchorbanov B, Marinova M, Grozeva L (2011). Debittering of Protein Hydrolysates by Lactobacillus LBL-4 Aminopeptidase. Enzym. Res. 538676:7.

Thivierge N (1999). Caractérisation de souches de Lactococcus lactis ssp cremoris pour le développement de ferments mésophiles à aptitude fromagère élevées (cheddar). Thesis for obtaining the degree of Master of Science. Canada.

Tobiassen RO, Sorhaug T, Stepaniak L (1997). Characterization of an intracellular oligopeptidase from Lactobacillus paracasei. Appl. and envir. J. Microbiol. 63:1284-1287.

Tsakalidou E, Dalezios I, Georgalaki M, Kalantzopoulos G (1993). A comparative study: Aminopeptidase activities from Lactobacillus delbrueckii ssp. Bulgaricus and Streptococcus thermophilus. J. Dairy Sci. 76:2145-2151. 